\title{
Melatonin influence in ovary transplantation: systematic review
}

\author{
M. E. Shiroma ${ }^{1 *}$, N. M. Botelho ${ }^{2}$, L. L. Damous ${ }^{3}$, E. C. Baracat ${ }^{1}$ and J. M. Soares-Jr ${ }^{1}$
}

\begin{abstract}
Melatonin is an indolamine produced by the pineal gland and it can exert a potent antioxidant effect. Its free radical scavenger properties have been used to advantage in different organ transplants in animal experiments. Several concentrations and administration pathways have been tested and melatonin has shown encouraging beneficial results in many transplants of organs such as the liver, lungs, heart, pancreas, and kidneys. The objective of the present study was to review the scientific literature regarding the use of melatonin in ovary transplantation. A systematic review following the Preferred Reporting Items for Systematic Reviews and Meta-Analyses (PRISMA) statement was carried out using the Cochrane and Pubmed databases and employing the terms 'melatonin' AND 'ovary' AND 'transplantation.' After analysis, 5 articles were extracted addressing melatonin use in ovary transplants and involving 503 animals. Melatonin enhanced various graft aspects like morphology, apoptosis, immunological reaction, revascularization, oxidative stress, and survival rate. Melatonin's antioxidative and antiapoptotic properties seemingly produce positive effects on ovarian graft activity. Despite the promising results, further studies in humans need to be conducted to consolidate its use, as ovary transplantation for fertility preservation is gradually being moved from the experimental stage to a clinical setting.
\end{abstract}

Keywords: Melatonin, Ovary, Transplant

\section{Background}

Melatonin is an indolamine produced mainly by the pineal gland $[1,2]$ and it has a potent freeradical scavenger activity with subsequent antioxidant and antiapoptotic functions $[1,3,4]$. Unlike vitamin $C$, which is hydrophilic, and vitamin $\mathrm{E}$, which is lipophilic, the melatonin molecule carries both hydrophilic and lipophilic affinities and therefore diffuses broadly in diverse subcellular compartments like the membranes, cytoplasm, nucleus, and mitochondria $[1,4]$. It has thus the ability to produce its antioxidative action rapidly and effectively as soon as the oxidative agents are produced [5]. There are reports about melatonin action on the rat ovary specific receptors MT1 and MT2 [6].

There are also studies indicating that one of the main challenges in achieving a successful transplant, is the reduction in graft follicular loss and damage. This is

\footnotetext{
* Correspondence: meshiroma@gmail.com

'Disciplina de Ginecologia, Departamento de Obstetrícia e Ginecologia, Hospital das Clínicas, Faculdade de Medicina, Universidade de São Paulo, Av. Dr. Enéas de Carvalho Aguiar, 255 - Cerqueira César, São Paulo, SP 05403-000, Brazil

Full list of author information is available at the end of the article
}

attainable through mitigation of the free radicals produced by the procedure [7] and primarily originating from ischemia-reperfusion distress [5]. Melatonin's immunological and antiapoptotic properties are seen as potentially implicated in the enhancement of transplantation success [5], a welcome improvement even in heterologous and autologous grafting. There are other studies demonstrating the benefits of melatonin in experimental transplants of organ, like the liver [8], lungs [9], heart [10], pancreas [11, 12] and kidneys [13]. Enhancement of the graft function, immunological compliance, and antiapoptotic and antioxidative status are examples of the positive outcome.

As there is evidence that melatonin's properties may experimentally improve the transplants of a variety of organs along different pathways, the aim of this review was to gather published studies of the indolamine's use in ovary transplantation.

\section{Methods}

In this systematic review, the PubMed and Cochrane databases were searched for reports published in any 
language between October 1, 2003 - date of the first ever published related paper [14] - and October 31, 2015, with the search terms: 'melatonin' AND 'ovary' AND 'transplantation.'

Data were extracted from the selected articles. Quality assessment was performed independently by two reviewers (M.E.S. and N.M.B.). When there was any disagreement, a third reviewer (L.L.D.) was consulted. The analysis followed the PRISMA statement for systematic reviews [15].

Six studies were identified and after detailed analysis of the content, one of them [16] was excluded for issue discrepancy (Fig. 1).

\section{Results}

All of the selected studies were published in the 12 years previous to this review. A total of 503 rodents (mice and rats) were studied. There are no reports of animal loss. Notwithstanding a study which used 5 human xenotransplanted ovarian samples, all were studies which experimentally analyzed the effects of melatonin on animals.

Except in the pioneer study by Sapmaz [14], who employed fresh ovaries, in all other researches, grafts were frozen and thawed. Many different concentrations (for the maintenance solution of the graft) and application routes (oral and intraperitoneal) were studied. Two studies adopted similar methodology and could be paired [17, 18].

The biological effects of melatonin on graft were enhancement of morphology; revascularization; and improved survival rate with concomitant reduction in apoptosis, immunological Th1/Th2 lymphocyte reaction, and oxidative stress (a decrease in oxidative factors and an increase in antioxidative agents). Results are summarized in Table 1.

\section{Conclusions}

The potential effects of melatonin use in animal ovary transplantation align with previously reported positive findings of its application in many experimental transplants of such organs as the liver [8], lungs [9], heart [10], pancreas [11, 12] and kidneys [13].

In our review we found evidence of the effects of melatonin on ovarian graft. Notwithstanding the administration routes (oral or intraperitoneal) and vehicles (graft), the selected studies reported a promising performance of the indolamine. This points to a wide solubility which enables it to spread rapidly throughout a variety of tissues. The effects comprised a wide range of properties, including follicle morphology and dynamics, apoptosis, graft survival range, immunologic activity and antioxidative mechanisms. The potent antioxidative properties of melatonin, along with its free radical scavenger activity, decrease oxidative stress and thus increase the survival rate. Melatonin not only acts directly as an anti-free radical agent, but also activates other enzymes, such as superoxide dismutase, glutathione peroxidase, and catalase $[20,21]$, with the potential to decrease oxidative damage. Even melatonin metabolites have free radical scavenger properties, thus triggering multiple synergistic antioxidative factors, a phenomenon referred to as the cascade effect $[20,21]$. The antiapoptotic effect was also remarkable and is based on reduction of $\mathrm{Bcl} 2$ expression and caspase-3 activity [22]. The enhancement of ovarian graft function is also attributable to melatonin, given that it is known to modulate steroidogenesis and ovulatory function $[23,24]$. The subsequent balance between free radicals and antioxidative substances in the ovarian follicle also improves oocyte and granulosa cell function [1, 2, 21]. Additionally, the indol also attenuated immunological reaction and improved
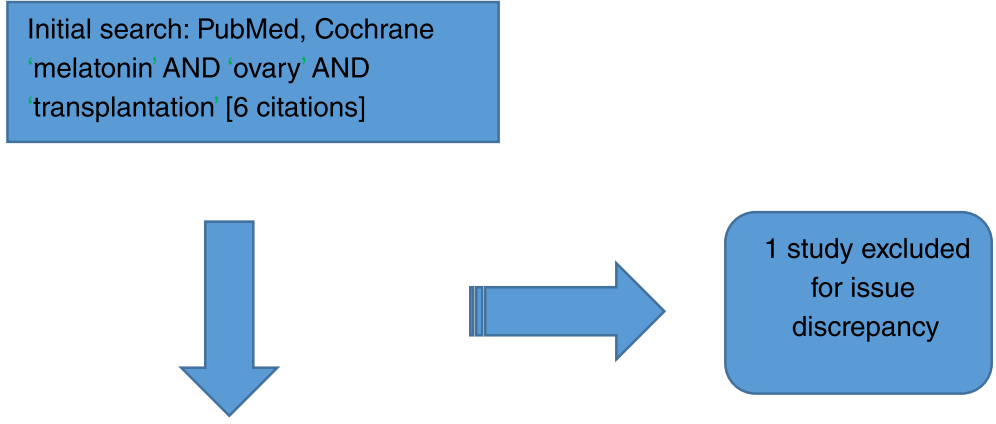

5 studies included in the review

Fig. 1 Algorithm of selected studies 
Table 1 Effects of melatonin on ovary transplantation

\begin{tabular}{|c|c|c|c|c|}
\hline Author & Species & Study model & Melatonin route and dosage & Results of melatonin use \\
\hline $\begin{array}{l}\text { Friedman, } \\
2012[3]\end{array}$ & $\begin{array}{l}\text { Human; Nu/nu } \\
\text { Balb/c mice }\end{array}$ & $\begin{array}{l}\text { Xenotransplanted thawed graft; donor: } 5 \text { cancer patients } \\
\text { aged 6-23 years; recipient: } 79 \text { immunodeficient nu/nu } \\
\text { Balb/c mice aged 10-12 weeks }\end{array}$ & $\begin{array}{l}\text { Oral administration in feeding } \\
\text { water; } 240 \mathrm{mg} / \mathrm{L}\end{array}$ & Reduced number of apoptosis and atretic follicles \\
\hline $\begin{array}{l}\text { Hemadi, } \\
2012[19]\end{array}$ & Balb/c mice & $\begin{array}{l}\text { Heterologous thawed graft; donor: mice aged } 10 \text { days; recipient: } 180 \\
\text { mice aged 8-10 weeks; } 900 \text { transplants }\end{array}$ & $\begin{array}{l}\text { Oral administration; } 20-200 \text { mg/ } \\
\mathrm{kg} / \text { day }\end{array}$ & $\begin{array}{l}\text { Enhanced follicle quality, quantity, and graft size with low } \\
\text { dosage; diminished Th1/Th2 immunological reaction and } \\
\text { longer graft lifespan with high dosage }\end{array}$ \\
\hline $\begin{array}{l}\text { Hemadi, } \\
2011[18]\end{array}$ & F1 hybrid mice & $\begin{array}{l}\text { Heterologous thawed graft; donor: mice aged } 10 \text { days; recipient: } 60 \\
\text { mice aged 8-10 weeks }\end{array}$ & $\begin{array}{l}\text { Graft: } 100 \mu \mathrm{M} \text { PBF } \\
\text { Recipient: intraperitoneal for } \\
2 \text { days; } 20 \mathrm{mg} / \mathrm{kg} / \text { day }\end{array}$ & Enhanced corpora lutea, secondary and antral follicles \\
\hline $\begin{array}{l}\text { Hemadi, } \\
2009[17]\end{array}$ & F1 hybrid mice & $\begin{array}{l}\text { Heterologous thawed graft; donor: } 120 \text { mice aged } 10 \text { days; recipient: } \\
36 \text { mice aged 8-10 weeks }\end{array}$ & $\begin{array}{l}\text { Graft: } 100 \mu \mathrm{M} \text { PBF } \\
\text { Recipient: intraperitoneal for } \\
2 \text { days; } 20 \mathrm{mg} / \mathrm{kg} / \text { day }\end{array}$ & $\begin{array}{l}\text { Improved mean graft survival, ovary size, and } \\
\text { revascularization }\end{array}$ \\
\hline $\begin{array}{l}\text { Sapmaz, } \\
2003[14]\end{array}$ & Wistar albino rats & $\begin{array}{l}\text { Autologous fresh graft; } 28 \text { Wistar albino rats aged } \\
12-14 \text { weeks }\end{array}$ & $\begin{array}{l}\text { intraperitoneal prior to } \\
\text { transplantation; } 20 \mathrm{mg} / \mathrm{kg}\end{array}$ & $\begin{array}{l}\text { Diminished ovarian and plasmatic malondialdehyde and } \\
\text { ovarian necrosis; enhanced glutathione peroxidase and } \\
\text { superoxide dismutase }\end{array}$ \\
\hline
\end{tabular}


revascularization, two essential properties for a successful graft allocation.

The present review has some limitations imposed by the studies it covered. The heterogeneity of methods made it difficult to compare results. The wide range of apparently beneficial melatonin action on ovarian transplantation is quite encouraging, but melatonin was studied only in animal models. Moreover, except for the Sapmaz [14] study, the other studies employed heterologous or xenotransplantation, which differs from clinical preservation of human fertility, for this method requires autologous transplantation. Melatonin was administered in the feeding water in two studies $[3,19]$. Therefore, different water intake by the animals might have resulted in diverse plasmatic concentration of melatonin. Apart from Hemadi [19], who dosed melatonin plasmatic levels, the authors did not determine the in vivo availability of melatonin in blood or urine. Furthermore, no study used control animals (not even pinealectomized rodents or rodents submitted to continuous light) to isolate the effect of endogenous melatonin production.

Melatonin's antioxidative and antiapoptotic properties seem to produce positive effects on ovarian graft. Despite the promising results, further studies are needed in humans to consolidate its use, as ovary transplantation for fertility preservation is gradually being moved from the experimental stage to a clinical setting.

\section{Abbreviation}

PRISMA, Preferred Reporting Items for Systematic Reviews and Meta-Analyses

\section{Acknowledgements}

Authors do not have any other professional to acknowledge for the manuscript elaboration.

\section{Funding}

No funding resource was involved in this manuscript.

\section{Availability of data and material}

Not applicable.

\begin{abstract}
Authors' contributions
MES and NMB performed the independent articles selection, quality assessment and review text elaboration; LLD performed article quality assessment and review text review; JMS and ECB provided review text review. All authors read and approved the final manuscript.
\end{abstract}

\section{Authors' information}

No further information to be noted.

\section{Competing interests}

The authors declare that have no conflict of interest regarding the elaboration of this manuscript.

\section{Consent for publication}

Not applicable.

\section{Ethics approval and consent to participate}

Not applicable.

\section{Author details}

'Disciplina de Ginecologia, Departamento de Obstetrícia e Ginecologia, Hospital das Clínicas, Faculdade de Medicina, Universidade de São Paulo,
Av. Dr. Enéas de Carvalho Aguiar, 255 - Cerqueira César, São Paulo, SP 05403-000, Brazil. 2Disciplina de Ginecologia, Departamento de Obstetrícia e Ginecologia, Faculdade de Medicina, Universidade Federal do Pará, Av. Generalíssimo Deodoro, 01 - Umarizal, Belém, Pará 66050-160, Brazil. ${ }^{3}$ Laboratory of Molecular and Structural Gynecology, Faculdade de Medicina, Universidade de São Paulo, Avenida Doutor Arnaldo, 455 - Cerqueira César, São Paulo, SP 01246-904, Brazil.

Received: 18 April 2016 Accepted: 7 June 2016

Published online: 10 June 2016

\section{References}

1. Reiter RJ, Tan DX, Manchester LC, Paredes SD, Mayo JC, Sainz RM. Melatonin and reproduction revisited. Biol Reprod. 2009;81:445-56.

2. Tamura H, Takasaki A, Taketani T, Tanabe M, Kizuka F, Lee F, et al. The role of melatonin as an antioxidant in the follicle. J Ovarian Res. 2012;5:5.

3. Friedman OR, Orvieto R, Fisch B, Felz C, Freud E, Ben-Haroush A, et al. Possible improvements in human ovarian grafting by various host and graft treatments. Hum Reprod. 2012;27:474-82.

4. Wang F, Tian XZ, Zhang L, Tan DX, Reiter RJ, Liu GS. Melatonin promotes the in vitro development of pronuclear embryos and increases the efficiency of blastocyst implantation in murine. J Pineal Res. 2013;55:267-74.

5. Reiter RJ, Maestroni GJM. Melatonin in relation to the antioxidative defense and immune systems: possible implications for cell and organ transplantation. J Mol Med. 1999;77:36-9.

6. Soares-Jr JM, Masana MI, Ersahin C, Dubocovich ML. Functional melatonin receptors in rat ovaries at vários stages of the estrous cycle. J Pharmacol Exp Ther. 2003;306:694-702.

7. Demeestere I, Simon P, Emiliani S, Delbaere A, Englert Y. Orthotopic and heterotopic ovarian tissue transplantation. Human Reprod Update. 2009;0:1-17

8. Vairetti M, Ferrigno A, Bertone R, Rizzo V, Richelmi P, Bertè F, et al. Exogenous melatonin enhances bile flow and ATP levels after cold storage and reperfusion in rat liver: implications for liver transplantation. J Pineal Res. 2005;38:223-30.

9. Inci I, Inci D, Dutly A, Boehler A, Weder W. Melatonin attenuates posttransplant lung ischemia-reperfusion injury. Ann Thorac Surg. 2002;73:220-5.

10. Jung FJ, Yang L, Harter L, Inci I, Schneiter D, Lardinois D, et al. Melatonin in vivo prolongs cardiac allograft survival in rats. J Pineal Res. 2004;37:36-41.

11. García-Gil FA, Albendea CD, Escartín J, Lampreave F, Fuentes-Broto L, Roselló-Catafau J, et al. Melatonin prolongs graft survival of pancreas allotransplants in pigs. J Pineal Res. 2011;51:445-53.

12. Lin GJ, Huang S-H, Chen Y-W, Hueng D-Y, Chien M-W, Chia W-T, et al. Melatonin prolongs islet graft survival in diabetic NOD mice. J Pineal Res. 2009:47:284-92.

13. Li Z, Nickkholgh A, Yi X, Bruns H, Gross M-L, Hoffmann K, et al. Melatonin protects kidney grafts from ischemia/reperfusion injury through inhibition of NF-kB and apoptosis after experimental kidney transplantation. J Pineal Res. 2009:46:365-72.

14. Sapmaz E, Ayar A, Celik H, Sapmaz T, Kilic N, Yasar MA. Effects of melatonin and oxytetracycline in autologous intraperitoneal ovary transplantation in rats. Neuroendocrinol Lett. 2003;24:350-4.

15. Shamseer L, Moher D, Clarke M, Ghersi D, Liberati A, Petticrew M, et al. Preferred reporting items for systematic review and meta-analysis protocols (PRISMA-P) 2015: elaboration and explanation. BMJ. 2015;350:g7647.

16. Zhang L, Chai M, Tian X, Wang F, Fu Y, He C, et al. Effects of melatonin on superovulation and transgenic embryo transplantation in small-tailed han sheep (Ovis aries). Neuro Endocrinol Lett. 2013:34:294-301.

17. Hemadi M, Abolhassani F, Akbari M, Sobhani A, Pasbakhsh P, ÄhrlundRichter $\mathrm{L}$, et al. Melatonin promotes the cumulus-oocyte complexes quality of vitrified-thawed murine ovaries; with increased mean number of follicles survival and ovary size following heterotopic transplantation. Eur J Pharmacol. 2009:618:84-90.

18. Hemadi M, Saki G, Shokri S, Ghasemi FM. Follicular dynamics in neonate vitrified ovarian grafts after host treatment with melatonin. Folia Morphol. 2011;70:18-23.

19. Hemadi M, Shokri S, Pourmatroud E, Moramezi F, Khodadai A. Follicular dynamic and immunoreactions of the vitrified ovarian graft after host treatment with variable regimens of melatonin. Am J Reprod Immunol. 2012;67:401-12 
20. Ferreira CS, Carvalho KC, Maganhin CC, Paiotti AP, Oshima CT, Simões MJ, Baracat EC, Soares JM Jr. Does melatonin influence the apoptosis in rat uterus of animals exposed to continuous light? Apoptosis. 2016;21(2):155-62.

21. Cruz MHC, Leal CLV, Cruz JF, Tan DX, Reiter RJ. Essential actions of melatonin in protecting the ovary from oxidative damage. Theriogenology. 2014:82:925-32.

22. Ferreira CS, Maganhin CC, Simões RS, Girão MJBC, Baracat EC, Soares-Jr JM. Melatonina: modulador de morte celular. Rev Assoc Med Bras. 2010;56:715-8.

23. Maganhin CC, Carbonel AAF, Hatty JH, Fuchs LFP, Oliveira-Junior IS, Simões MJ, et al. Efeitos da melatonina no sistema genital feminino: breve revisão. Rev Assoc Med Bras. 2008:54:267-71.

24. Romeu LRG, Motta ELA, Maganhin CC, Oshima CTF, Fonseca MC, Barrueco $\mathrm{KF}$, et al. Effects of melatonin on histomorphology and on the expression of steroid receptors, VEGF, and PCNA in ovaries of pinealectomized female rats. Fertil Steril. 2011;95:1379-1384A.

Submit your next manuscript to BioMed Central and we will help you at every step:

- We accept pre-submission inquiries

- Our selector tool helps you to find the most relevant journal

- We provide round the clock customer support

- Convenient online submission

- Thorough peer review

- Inclusion in PubMed and all major indexing services

- Maximum visibility for your research

Submit your manuscript at www.biomedcentral.com/submit
Biomed Central 